\title{
The Effect of Alfha Angle Variation Sudu Rotor Blade On Wind Turbine Performance Using Blade NACA 0018
}

\section{Pengaruh Variasi Sudut Alfa Sudu Rotor Blade Terhadap Unjuk Kerja Wind Turbine Dengan Menggunakan Blade NACA 0018}

\author{
M Habibullah ${ }^{1}$, Rachmad Firdaus $^{2)}$ \\ [mhabibullah914@gmail.com ${ }^{1}$,firdausr@umsida.ac.id ${ }^{2}$ ]
}

Program Studi Teknik Mesin, Fakultas Sains dan teknologi, Universitas Muhammadiyah Sidoarjo

\begin{abstract}
Indonesia currently has a growing need for energy, this will experience an energy crisis condition, dependence on fossil fuels will at least pose a serious threat, therefore there must be alternative energy as a substitute and reserves such as wind energy, water energy, solar energy, and other. Because Indonesia has abundant water sources, with this my research intends to develop water as a renewable energy source that can be used as a source of energy for hydroelectric power plants or also called water turbines. The water turbine is an early generator that uses the potential energy of water to become mechanical energy where the water turns the turbine wheel. This study aims to determine the effect of the number of blades, the effect of the profile, the effect of rotor blade wing tip, Naca 0018, and the resulting energy efficiency. This research uses experimental research type.
\end{abstract}

Keywords - wind turbine naca 0018; experiment performance test.

Abstrak- Indonesia saat ini mempunyai kebutuhan energi yang semakin besar hal ini akan mengalami kondisi krisis energi, ketergantungan terhadap bahan bakar fosil setidaknya akan memiliki ancaman yang serius, oleh karena itu harus ada energi alternative sebagai pengganti dan cadangan seperti energi angin, energi air, energi surya, dan lainya. Dikarnakan Indonesia memiliki sumber energi angin didaerah-daerah pesisir pantai yang melimpah maka dengan ini penelitian saya bermaksud untuk mengembangkan energi angin sebagai salah satu sumber energi terbarukan yang dapat dijadikan sumber energi bagi pembangkit listrik tenaga angin atau juga di sebut dengan turbin angin. Turbin angin adalah suatu pembangkit mula-mula yang memanfaatkan energi potensial angin menjadi energi mekanik dimana angin memutar roda turbin. pada penelitian ini bertujuan untuk mengetaahui pengaruh jumlah blade, pengaruh variasi sudut, pengaruh wing tip sudu rotor, naca 0018 dan efisiensi energi yang dihasilkan. Penelitian ini menggunakan jenis penelitian eksperimen.

Kata Kunci - turbin angin naca 0018; uji eksperimen performa

\section{PENDAHULUAN}

Pentingya kebutuhan energi di kehidupan manusia, menjadikan suatu hal yang tidak bisa terlepaskan dalam aktifitas sehari hari, begitupun juga energi listrik. Ketergantungan manusia dengan energi listrik memang tidak bisa di pisahkan. Populasi manusia yang terus berkembang pesat menjadikan kebutuhan energi listrik semakin meningkat, dengan prediksi populasi manusia pada tahun yang akan mendatang yaitu tahun 2050 kedepan akan meningkatnya populasi manusia menjadi 9 (sembilan) miliyar dari angka 7 (tujuh) miliyar pada awal abad 21 [1].

Peningkatan kebutuhan listrik bagi kehidupan sehari hari sudah terlihat jelas, yang pertama berasal dari rumah rumah warga, yg kedua dari usaha kecil menengah atau para penduduk yang memenuhi kebutuhanya dengan cara berbisnis (home industri), yang ketiga merupakan instansi atau perusahaan yang membutuhkan energi listrik yang begitu besar yang digunakan untuk mengoprasikan beberapa kinerja industrinya termasuk jalanya mesin produksi dan lain lain. Diketahui kebutuhan listrik di tanah jawa dari tahun yang lalu ada sekitar 69,96 Twh pada tahun 2013, sekarang pada tahun 2020 yang di ketahui tanah jawa merupakan kawasan industry terbesar di Indonesia sehingga energi yang dibutuhkan semakin meninggkat menjadi 203,19 Twh. Itulah mengapa Indonesia harus mempunyai sumber energi yang terbarukan sehingga akan membantu pengurangan sumber energi listrik [2].

Diketahui Indonesia memiliki potensi dengan sumber daya alam yang melimpah yang bisa digunakanan dalam pengelolahan pembangkit listrik yaitu sungai, waduk, batu bara, dan udara. Berdasarkan sumber daya alam yang dapat berpotensi sebagai bahan utama pembangkit listrik, maka perlu dilakukan pemanfaatan sumber daya alam untuk menyelesaikan masalah ketersediaan listrik. Oleh karena itu, diperlukan ide dan gagasan untuk membahas dan menganalisis pengaruh variasi sudut alfa sudu rotor blade terhadap unjuk kerja wind turbine dengan menggunakan blade naca 0018. Hal ini bertujuan untuk langkah awal menciptakan alat pembangkit listrik tenaga angin dengan menggunakan blade naca 0018 [3]. 


\section{A. Turbin Angin}

Turbin angin adalah kincir angin yang digunakan untuk membangkitkan tenaga listrik. Turbin angin ini pada awalnya dibuat untuk mengakomodasi kebutuhan para petani dalam melakukan keperluan pengairan irigasi, penyelepan padi dll. Turbin angin terdahulu banyak dibangun di Denmark Belanda dan negara eropa lainnya dan lebih dikenal dengan Windmill [4].

Kini turbin angin lebih banyak digunakan untuk mengakomodasi kebutuhan listrik masyarakat dengan menggunakan prinsip konversi energi dan menggunakan sumber daya alam yang dapat diperbaharui yaitu angin, walaupun sampai saat ini pembangunan turbin angin masih belum dapat menyaingi listrik konvensional seperti: PLTD, PLTU turbin angin masih dikembangkan oleh para ilmuwan karena dalam waktu dekat manusia akan dihadapkan dengan masalah kekurangan sumber daya alam yang tidak dapat diperbaharui seperti: batu bara, minyak bumi [5].

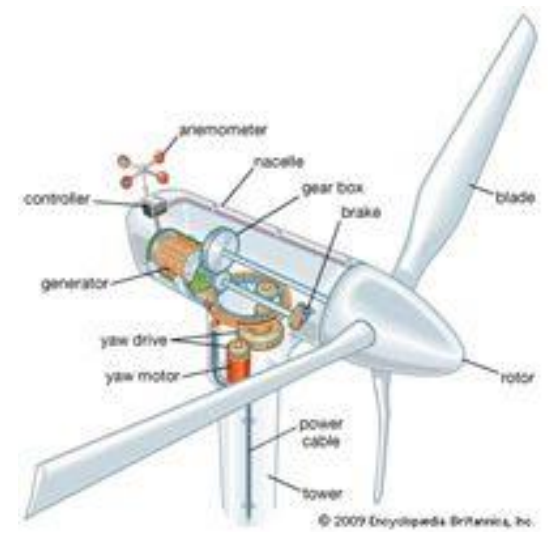

Gambar 1. Wind Turbine Subsystems

Dibawah ini adalah keterangan pada gambar 1 sebagai berikut:

1. Turbine Blades yaitu sudu pembatas bertujuan untuk mencampur energi antara gas dan suhu.

2. Stator dan Rotor yaitu generator atau alternator listrik.

3. Generator yaitu mesin yang dapat merubah tenaga mekanis menjadi tenaga listrik melalui proses induksi elektromagnetik.

4. Turbine Generator Shaft yaitu poros turbin.

5. Anemometer yaitu sebuah perangkat untuk mengukur kecepatan angin dan untuk mengukur arah angin [6].

\section{METODE}

Data yang diambil dalam pengujian eksperimental ini adalah untuk mengetahui perbandingan peningkatan performa putaran turbin angin terhadap pengaruh variasi sudut alfa pada sudu rotor blade, pada metode penelitian ini dimulai dari langkah-langkah persiapan bahan dan rancangan bentuk airfoil turbin angin yang akan dilakukan dalam proses penelitian, beberapa bahan yang dibutuhkan antara lain lembaran plat alumunium dengan ketebalan mulai dari $0,6 \mathrm{~mm}-1 \mathrm{~mm}$, pipa alumunium od $14 \mathrm{~mm} \times$ id $12 \mathrm{~mm}$, pipa aluminium od $12 \mathrm{~mm} x$ id $10 \mathrm{~mm}$ [7]. Bahan plat aluminium $1 \mathrm{~mm}$ akan di bentuk dan potong menjadi sebuah airfoil naca 0018 dengan jumlah yang dibutuhkan sebanyak 12 biji dan menggabungkan tiga airfoil menjadi sebuah kerangka sudu rotor blade. Setelah itu membuat cover pembungkus kerangka blade menggunakan plat aluminium 0,6mm hingga menutupi semua bagian kerangka sampai tidak ada bagian yang berlubang untuk menghidari kemasukan angin saat pengujian dan menjadi sebuah sudu rotor blade yang sempurna sesuai bentuk yang diinginkan disini dibutuhkan empat buah sudu rotor blade, kemudian pipa aluminium od $14 \mathrm{~mm} \times 12 \mathrm{~mm}$ dibuat sebagai poros penghubung antara turbin angin dengan generator untuk pipa aluminium od $12 \mathrm{~mm} \times 10 \mathrm{~mm}$ dibuat sebagai arm/penghubung antara keempat sudu rotor blade dengan poros yang akan berputar terdorong oleh aliran angin dan putaran ini akan menggerakkan generator yang dapat menghasilkan arus listrik dc [8].

Adapun pengujian dan pengambilan data yang akan dilakukan yaitu :

1. Pengujian A merupakan pengujian dan pengambilan data yang pertama dimana sudut alfa rotor blade belum dirubah, yang nantinya data hasil pengujian ditampilkan dalam bentuk tabel dan grafik [9].

2. Pengujian $B$ merupakan pengujian dan pengambilan data yang kedua pada turbin angin dengan merubah sudut alfa menjadi 0 derajat, 10 derajat, dan -10 derajat yang nantinya data hasil pengujian ditampilkan dalam bentuk tabel dan grafik. 


\section{HASIL DAN PEMBAHASAN}

\section{A. Langkah pembuatan dan perakitan}

Tahap awal pengukuran dan pembentukan daun airfoil yang nantinya akan kita bentuk sebagai kerangka awal sudu rotor dari turbin angin dimana bentuk dan ukuran airfoil naca 0018 seperti pada tabel berikut:

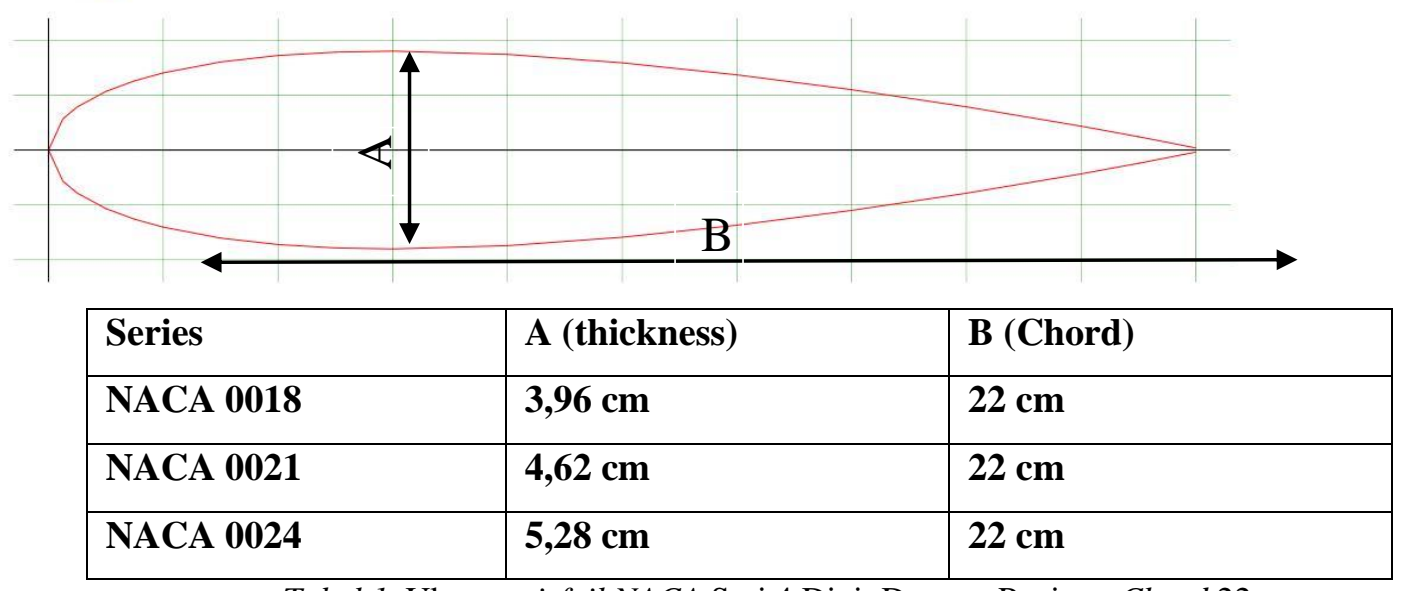

Tabel 1. Ukuran airfoil NACA Seri 4 Digit Dengan Panjang Chord $22 \mathrm{~cm}$

Setelah daun airfoil terbentuk sesuai ukuran lanjut menggabungkan sejumlah tiga airfoil menjadi kerangka sudu rotor blade dan berikut gambar langkah langkah pembuatan dan perakitan turbin angin.
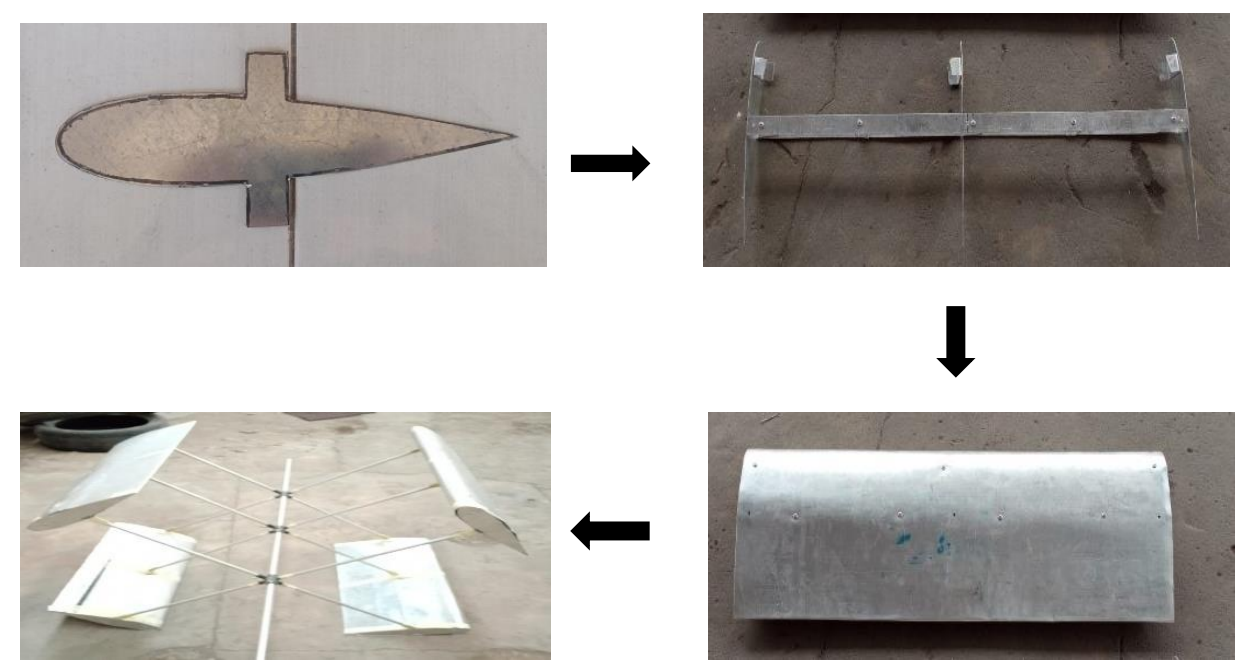

Gambar 2. Alur pembuatan dan perakitan turbin angin blade naca 0018

\section{B. Siklus kerja turbin angin}

Turbin angin mengubah energi kinetik dari aliran angin menjadi energi mekanik di poros turbin, secara sederhana dapat kita katakan bahwa aliran angin akan memutar turbin angin. Turbin tersebut akan menggerakkan generator yang terpasang pada turbin melalui pulley yang menghubungkan generator dengan turbin ini dihubungkan oleh fanbelt atau karet kemudian mengubah energi mekanik yang dihasilkan menjadi energi listrik, ini adalah prinsip dasar cara kerja pembangkit listrik tenaga angin [10].

Pembangkit listrik tenaga angin sangat populer dan digunakan hampir diseluruh negara termasuk di Indonesia, hal itu karena jenis pembangkit tenaga listrik lainnya yang menggunakan cadangan bahan bakar seperti minyak dan batubara semakin menipis setiap harinya. Jadi turbin angin ini memanfaatkan sumber daya alam yang melimpah di Indonesia terutama didaerah-daerah pesisir pantai yang terdapat banyak hampir diseluruh wilayah indonesia [11]. 


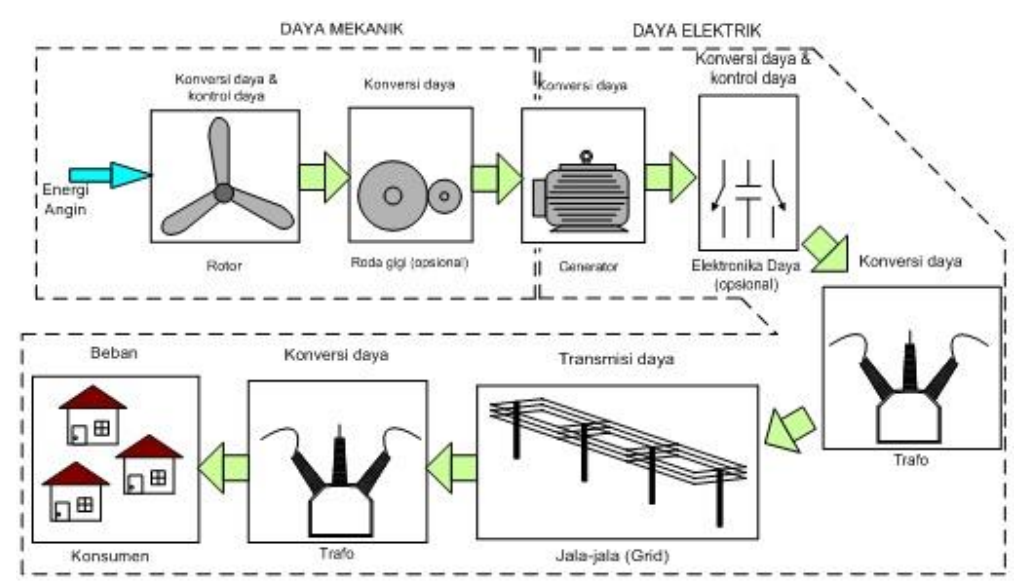

Gambar 3. Siklus kerja turbin angin

\section{Uji performa variasi sudut blade}

Pada tahap pengujian ini dilakukan setelah pembuatan turbin angin telah selesai pada tahap akhir untuk mengetahui performa kepecatan putar turbin angin, juga untuk mengukur tegangan listrik generator, untuk mengetahui arus listrik generator, untuk menghitung daya output dari generator, untuk mengetahui efisiensi generator. Untuk mengetahui hasil pengujian yang akurat dibutuhkan alat-alat pendukung untuk menunjang kinerja turbin angin diantaranya seperti generator, tachometer, voltmeter, ampere meter, anemometer.

Prosedur pengujian :

1. Langkah awal ketika selesai perakitan dilakukan quality control untuk mengetahui ada tidaknya lubang yang dapat menyebabkan kebocoran udara masuk kedalam rotor blade.

2. Langkah kedua memastikan arus aliran dan kedalaman sungai sudah sesuai dengan standart pengujian turbin angin.

3. Langkah ketiga melakukan pengecekan generator dan alat-alat pendukung lain untuk memastikan dalam keadan baik saat digunakan.

4. Catat dan dokumentasikan hasil pada saat pengujian [13].

\section{A. Hasil pengujian variasi sudut blade}

Pengujian dilakukan pada turbin angin dengan menggunakan blade naca 0018 berjumlah empat sudu. Pengujian ini bertujuan untuk mengetahui performa maksimal turbin angin pada variasi sudut alfa sudu rotor blade yang telah dirancang sehingga sudut sudu turbin bisa disesuaikan untuk mendapatkan performa maksimal pada turbin angin ini [12].

Berikut ini merupakan hasil dari pengujian unjuk kerja performa turbin angin, dimana data ini didapat dengan melakukan pengukuran menggunakan beberapa alat ukur seperti voltmeter, amperemeter, dan tachometer menggunakan aplikasi magnetic counter- rpm meter yang ada dihandphone android. Dibawah ini merupakan tabel hasil yang diperoleh dari pengujian yang dilakukan.

Tabel 2. Hasil pengujian variasi sudut alfa pada sudu turbin angin

\begin{tabular}{|c|c|c|c|}
\hline Sudut & Rpm & Volt & Ampere \\
\hline $\mathbf{- 2 0}$ & 1176 & 10,3 & 1,1 \\
\hline $\mathbf{- 1 5}$ & 1463 & 11,2 & 1,4 \\
\hline $\mathbf{- 1 0}$ & 1071 & 10,4 & 1 \\
\hline $\mathbf{0}$ & 1000 & 9,9 & 0,6 \\
\hline $\mathbf{1 0}$ & 983 & 9,1 & 0,2 \\
\hline $\mathbf{1 5}$ & 845 & 7,5 & 0 \\
\hline
\end{tabular}

Dari hasil beberapa pengujian variasi sudut alfa mulai dari sudut 15 derajat sampai minus 20 derajat dapat diketahui bahwa performa maksimal turbin angin ini terdapat pada sudut minus 15 derajat karena dapat berputar dengan kecepatan 1463 rpm dan menghasilkan voltase sebesar 11,2 volt dan 1,4 amper. Yang dapat dilihat pada grafik dibawah ini. 


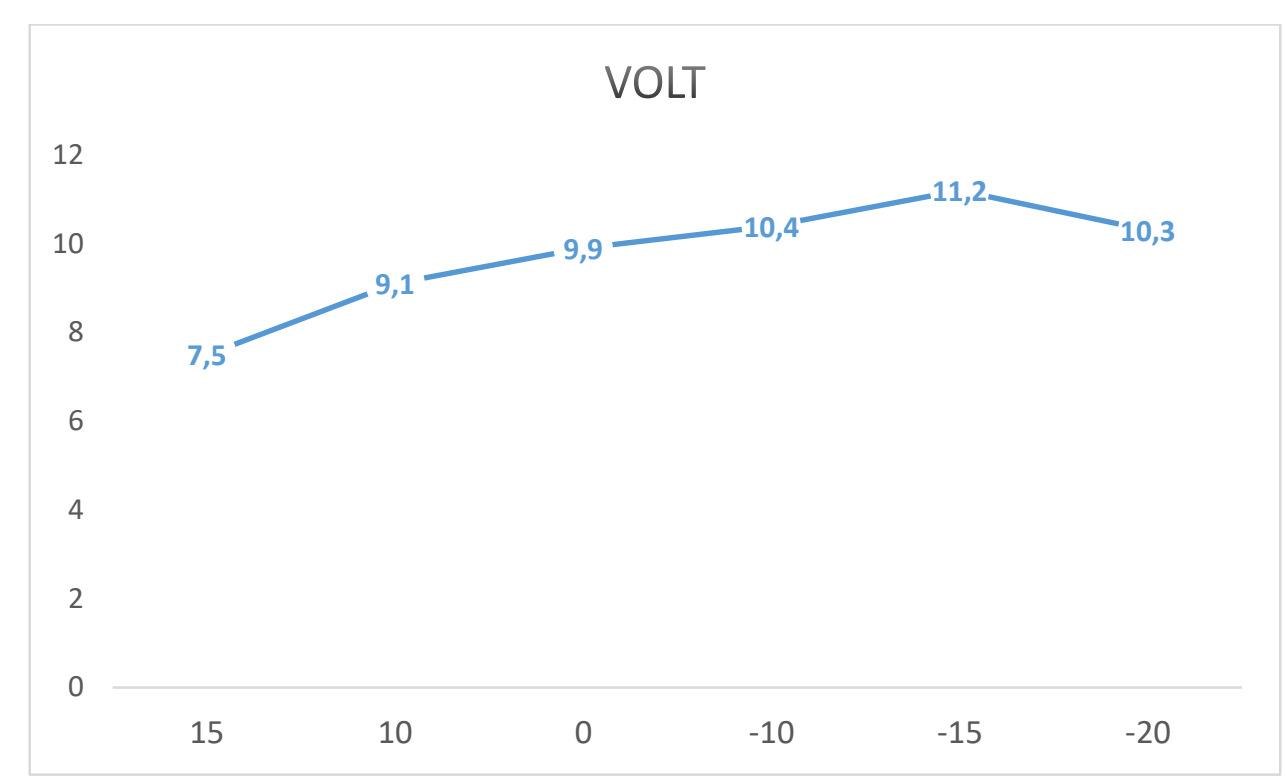

Gambar 4. Grafik voltase hasil dari pengujian variasi sudut sudu turbin angin

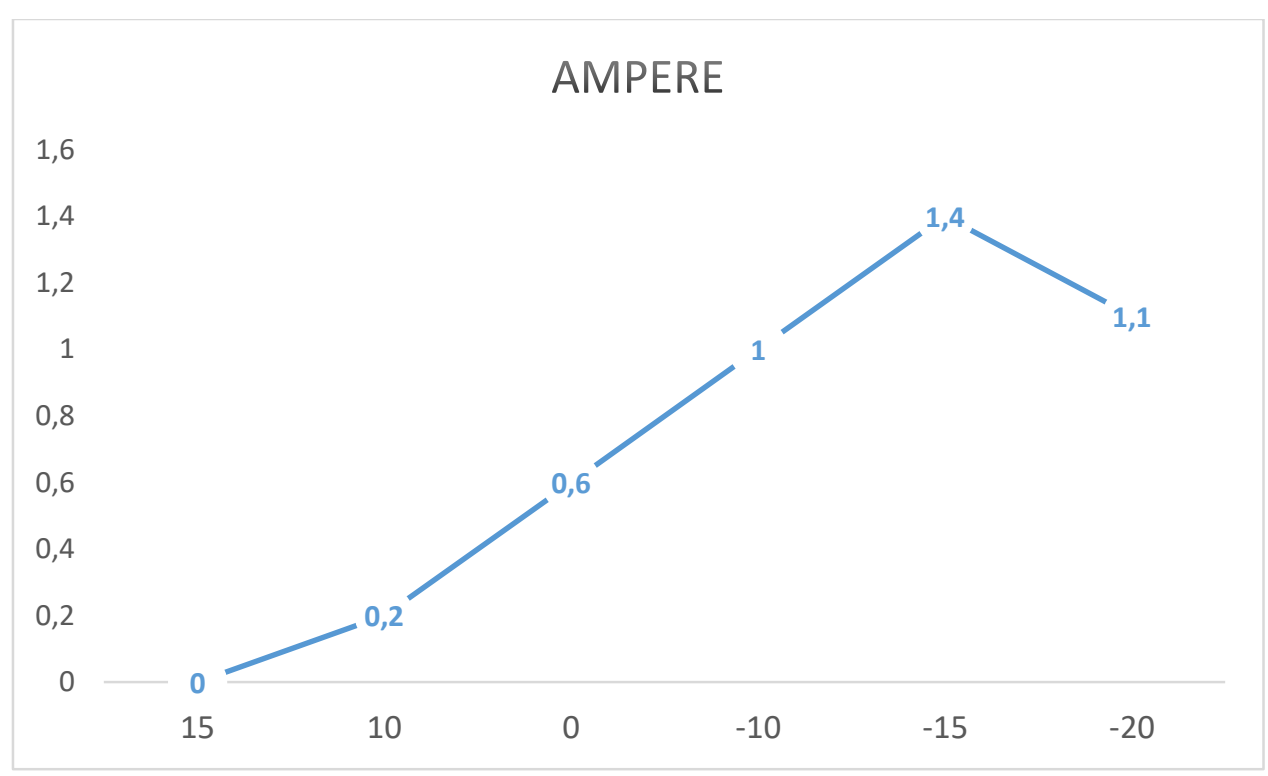

Gambar 5. Grafik ampere hasil dari pengujian variasi sudut sudu turbin angin

\section{KESIMPULAN}

Dari hasil pengujian dan analisa dapat disimpulkan bahwa jika dilihat dari performa putaran turbin angin terdapat peningkatan dengan cara melakukan perubahan variasi pada sudut alfa sudu turbin angin yang terdapat pada sudut minus 15 derajat, dari peningkatan ini juga dapat disimpulkan bahwa tegangan, arus, daya output pada generator dapat beroperasi dengan baik dan kinerja dari generator dapat berjalan dengan maksimal.

\section{UCAPAN TERIMA KASIH}

Dan tak lupa juga ucapan terimakasih kepada semua pihak yang telah turut membantu dalam kelancaran pembuatan turbin angin naca 0018 antara lain

1. Bapak Dr. Eng Rachmad Firdaus, ST, MT selaku dosen pembimbing

2. Rekan-rekan kerja bengkel jepang motor sidoarjo yang banyak memberi masukan dan solusi saat pembuatan turbin angin. 


\section{REFERENSI}

[1] Aresti, L., Tutar, M., Chen, Y., and Calay, R. Computational study of a small scale vertical axis wind turbine (VAWT): Comparative performance of various turbulence models, Wind and Structures, Vol.17, No.6(2013), pp.647-670.

[2] Fujisawa, N. and Shibuya, S., Observations of dynamic stall on Darrieus wind turbine blades, Journal of Wind Engineering and Industrial Aerodynamics, Vol.89 (2001), pp. 201-214.

[3] Howell, R., Qin, N., Edward, J. and Durrani, N., Wind tunnel and numerical study of a small vertical axis wind turbine, Renewable Energy, Vol.35 (2010), pp.412-422.

[4] Ross, I. and Altman, A., Wind tunnel blockage corrections: Review and application to Savonius vertical-axis wind turbines, Journal of Wind Engineering and Industrial Aerodynamics, Vol.99 (2011), pp.523-538.

[5] Kiwata, T., Yamada, T., Kita, T., Takata, S., Komatsu, N. and Kimura, S., Performance of a vertical axis wind turbine with variable-pitch straight blades utilizing a linkage mechanism, Journal of Environment and Engineering, Vol.5, No.1 (2010), pp.213-224.

[6] Larsen, J.W., Nielsen, S.R.K. and Krenk, S., Dynamic stall model for wind turbine airfoil, Journal of Fluid and Structures, Vol. 23 (2007), pp.959-982.

[7] Leifur Leifsson, Variable-Fidelity Aerodynamic Shape Optimization, Computational Optimization, Methods and Algorithms Studies in Computational Intelligence Volume 356, 2011, pp 179-2102011

[8] McNaughton, J. Billard, F. and Revell, A., Turbulence modelling of low Reynolds number flow effects around a vertical axis turbine at a range of tip-speed ratios, Journal of Fluids and Structures, Vol.47 (2014), pp.124-138.

[9] Menter F. R., Two-equation eddy-viscosity turbulence models for engineering applications, AIAA Journal, Vol.32, No.8 (1994), pp.1598-1605.

[10] Muvariz, M. F., \& Rossbandrio, W. (2015). Studi Gaya Drag dan Lift pada Blade Profile NACA 0018 Turbin Arus Laut Sumbu Vertikal. Jurnal Integrasi, 7(1), 40-44.

[11] Rahmadi, J., Yusuf, I., \& Priyatman, H. (2015). Joni rahmadi 2015. 7(1), 11-18.

[12] Resha, M., \& Yohanes, A. (2019). EFFECT OF AIRFOIL SHAPE ON THE AERODYNAMIC CHARACTERISTICS OF VERTICAL ROTOR WIND TURBINES. 9-10.

[13] Turbin, K., Vertical, A., Profil, A., Berbantuan, B., Vane, G., Nim, S., ... Indonesia, K. (n.d.). vertical axis. $1-8$. 